\title{
Flexural strength of acrylic resin repairs processed by different methods: water bath, microwave energy and chemical polymerization
}

\author{
João Neudenir ARIOLI FILHO'1, Luís Eduardo BUTIGNON², Rodrigo de Paula PEREIRA², Matheus Guilherme LUCAS², \\ Francisco de Assis MOLLO JUNIOR ${ }^{1}$
}

\begin{abstract}
1- DDS, MSc, PhD, Associated Professor, Department of Dental Materials and Prosthodontics, Araraquara Dental School, São Paulo State University, Araraquara, SP, Brazil.

2- DDS, MSc, Graduate student in Oral Rehabilitation, Department of Dental Materials and Prosthodontics, Araraquara Dental School, São Paulo State University, Araraquara, SP, Brazil.
\end{abstract}

Corresponding address: Prof. João Neudenir Arioli Filho - Faculdade de Odontologia de Araraquara - UNESP - Departamento de Materiais Odontológicos e Prótese - Rua Humaitá, 1680 - $4^{\circ}$ andar - 14801-903 - Araraquara, SP - Brasil - Phone: +55-16-3301-6406 - Fax: +55-16-3301-6406 - e-mail: arioli@foar.unesp.br

Received: July 20, 2009 - Modification: March 19, 2010 - Accepted: May 25, 2010

\section{ABSTRACT}

\begin{abstract}
$\mathrm{D}$ enture fractures are common in daily practice, causing inconvenience to the patient and to the dentists. Denture repairs should have adequate strength, dimensional stability and color match, and should be easily and quickly performed as well as relatively inexpensive. Objective: The aim of this study was to evaluate the flexural strength of acrylic resin repairs processed by different methods: warm water-bath, microwave energy, and chemical polymerization. Material and methods: Sixty rectangular specimens $(31 \times 10 \times 2.5$ $\mathrm{mm}$ ) were made with warm water-bath acrylic resin (Lucitone 550) and grouped (15 specimens per group) according to the resin type used to make repair procedure: 1 ) specimens of warm water-bath resin (Lucitone 550) without repair (control group); 2) specimens of warm water-bath resin repaired with warm water-bath; 3) specimens of warm water-bath resin repaired with microwave resin (Acron MC); 4) specimens of warm waterbath resin repaired with autopolymerized acrylic resin (Simplex). Flexural strength was measured with the three-point bending in a universal testing machine (MTS 810 Material Test System) with load cell of $100 \mathrm{kgf}$ under constant speed of $5 \mathrm{~mm} / \mathrm{min}$. Data were analyzed statistically by Kruskal-Wallis test $(p<0.05)$. Results: The control group showed the best result (156.04 $1.82 \mathrm{MPa})$. Significant differences were found among repaired specimens and the results were decreasing as follows: group $3(43.02 \pm 2.25 \mathrm{MPa})$, group $2(36.21 \pm 1.20 \mathrm{MPa})$ and group $4(6.74 \pm 0.85 \mathrm{MPa})$. Conclusion: All repaired specimens demonstrated lower flexural strength than the control group. Repairs with autopolymerized acrylic resin showed the lowest flexural strength.
\end{abstract}

Key-words: Flexural strength. Denture fracture. Denture repair.

\section{INTRODUCTION}

Fractures of the base of poly (methyl)methacrylate dentures are common in clinical practice, happening more frequently in the midline of maxillary complete dentures ${ }^{3,5}$. These fractures are often related to poor fit of the denture base $e^{4,16}$, poorly balanced occlusion ${ }^{4,16}$, problems in design and manufacturing of the denture ${ }^{4}$, poor strength of the repair material ${ }^{4,16}$, as well as inherent stress on the denture base that happens over time ${ }^{16,29}$.
Denture fractures occur outside and inside the mouth. Outside the mouth, they often occur as a consequence of impact (accidents), as a result of expelling the denture from the mouth while coughing, or simply of dropping the denture ${ }^{3,16,22}$. Inside, the causes of denture fracture can be excessive bite force, improper occlusal plane, high frenal attachment, lack of balanced occlusion, poor fit or limitations in denture base material ${ }^{1}$. When in function, midline fracture is the result of flexural fatigue failure caused by cyclic deformation of the base, and is more likely to occur because flexure of 
the denture base occurs along the midline ${ }^{21}$.

Denture repairs should have adequate strength, dimensional stability $4,16,22,27$, good color match $4,10,15,16,22,27$, are easily and quickly performed $16,18,27$, are relatively inexpensive ${ }^{10,15,27}$. Factors affecting adhesion and the mechanical properties of the repair material can influence the strength of the repaired denture. Attempts to improve the bond strength between the denture base resin and the repair material, through mechanical or chemical surface modification ${ }^{9,14,21,25,27}$, as well as the transverse strength, by metal wiring or fiber reinforcements ${ }^{10,11,14,18,25}$, have been described. The choice of denture base resin, as well as of the repair material may also influence the strength of the repaired denture $5,6,15,19,23,24$.

Heat-polymerized materials have been proven to have higher mechanical properties when compared with auto-polymerized materials $\mathbf{s}^{4,6,17}$. However, laboratory packing and flasking procedures are time consuming and present risk of denture distortion by heat ${ }^{8}$.

Comparing the different repair techniques, was described that acrylic resins, when polymerized under pressure and then stored in water, were more resistant than those polymerized by trade polymerization method ${ }^{13}$. Accordingly, considering the variability of the repair materials and the different repairing techniques, herein we aimed at assessing the flexural strength of acrylic resin repairs using different processing techniques. It is expected that the different methods of polymerization of acrylic resins used to repair specimens allow flexural strength values similar to those of the non-repaired specimens.

\section{MATERIAL AND METHODS}

One control and three experimental groups $(n=15)$ were formed according to the type of resin used for repairing specimens made of Lucitone 550 thermoactivated acrylic resin (Dentsply Trubite, York, PA, USA): 1) Control - no repair; 2) repair with Lucitone $550 ; 3)$ repair with Acron MC thermoactivated acrylic resin (GC Dental Ind. Corporation, Alsip, IL, USA); 4) repair with Simplex chemically activated acrylic resin (Artigos Odontológicos Clássicos, São Paulo, SP, Brazil).

Metal master pattern with rectangular cavities associated to a metal spacer bar with $3.0 \times 10.0 \times 2.5$ $\mathrm{mm}^{3}$ placed in the center of this pattern were used to make repaired specimens measuring $65.0 \times 10.0 \times 2.5$ $\mathrm{mm}^{3}$, according to the Specification No.12 of the American Dental Association (Figure 1).

Pattern was initially isolated with a thin layer of acrylic separating film (Cel-Lac, S.S. White, Rio de Janeiro, RJ, Brazil) and included in special flasks (Provecto Analítica, Jundiai, SP, Brazil) that can be used in the microwave oven reinforced with stone plaster type III Herodent (Cremer, São Paulo, SP, Brazil). With the plaster still fluid, one matrix was placed on each flask, maintaining its superior face exposed. After $60 \mathrm{~min}$, each matrix compartment was filled with liquid wax (Kota Imports, São Paulo, $\mathrm{SP}$, Brazil), and the counter flask was again filled with a new portion of stone plaster type III. The specimens of control group were made without use of the metal spacer bar.

After setting of the stone, the flask was opened and the wax was removed with hot water. The inner surface of the metal pattern was coated with acrylic separating film and the cavities were filled with acrylic resin (Lucitone 550), mixed according to the manufacturer's instructions, keeping the metal spacer bar placed only to groups 2, 3 and 4 . The flask was closed to be pressed in a hydraulic press (Delta, Delta Máquinas Especiais, Vinhedo, SP, Brazil). A cellophane sheet was placed over acrylic resin before the flask was closed. The initial pressing was carried out with $800 \mathrm{~kg}$ to eliminate excess resin. Then, the flask was opened, the cellophane sheet was removed and a second pressing was carried out with $1,250 \mathrm{~kg}$ for $30 \mathrm{~min}$. After this

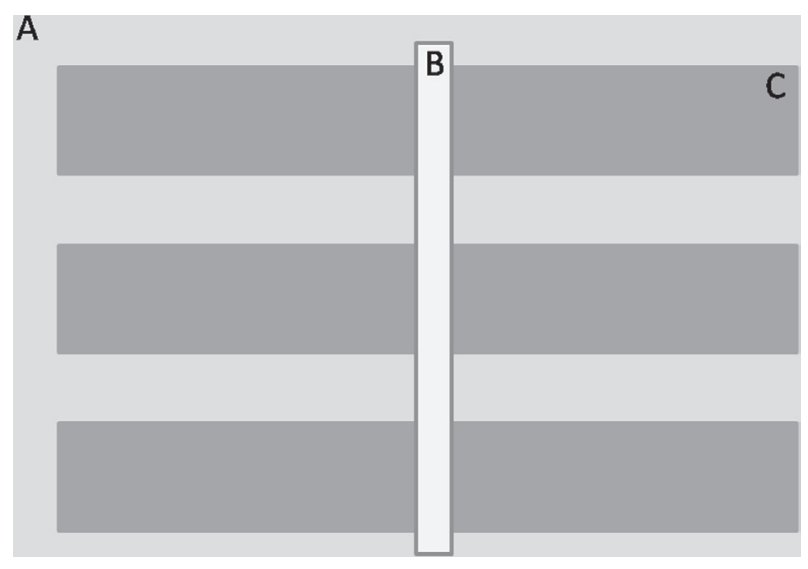

Figure 1-A) Metal master pattern; B) Spacer Bar, and C) Rectangular cavities

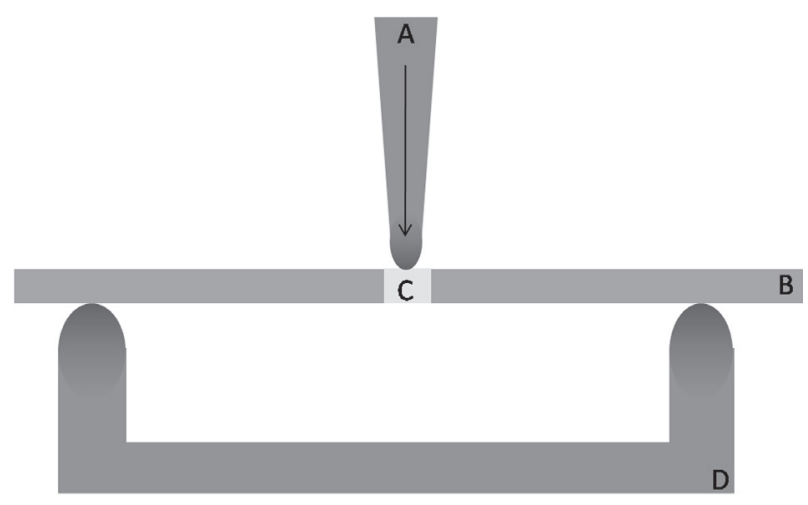

Figure 2- Scheme of test in MTS 810: A) round-end point, B) resin specimen, C) resin repair, and D) support for specimen 
procedure, the flask was immersed in water at $74^{\circ} \mathrm{C}$ for $9 \mathrm{~h}$ in a polymerization unit (Termotron $\mathrm{P}-100$, Termotron do Brasil Ltda, São Paulo, SP, Brazil). After being left at room temperature $\left(26^{\circ} \mathrm{C}\right)$, the flasks were carefully opened and the metal spacer bar was removed. The acrylic specimens were also removed and abraded with 200-, 400-, 600-, 1000-, 1500-grit silicon carbide paper (Norton, Comercial e Técnica de Abrasivos Ltda., Campinas, SP, Brazil) in a decreasing sequence of abrasiveness, followed by final polishing with $1 \mu \mathrm{m}$ diamond paste. All specimens were stored in distilled water at $37^{\circ} \mathrm{C}$ for 1 week before repair.

Each specimen was then replaced on the flaks in order to maintain a uniform space for the repair material and to determine the alignment of the specimens. For all groups butt joint surfaces without treatment was produced.

Upon removal of the space bar, the 2 sections of the specimens were repaired using the 3 different acrylic resins. In group 2, repairs were done with acrylic resin Lucitone 550, prepared according to the manufacturer's recommendations. Lucitone 550 resin was placed under compression (1250 kg) for $30 \mathrm{~min}$ at room temperature, and polymerized in short-cycle water bath $\left(60 \mathrm{~min}\right.$ under $100^{\circ} \mathrm{C}$ degrees $)^{26}$. Specimens of group 3 were repaired using acrylic resin Acron Mc, also under same compression for $30 \mathrm{~min}$, at room temperature $\left(23^{\circ} \mathrm{C}\right)$ and polymerized in a domestic microwave
(Sensor Crisp 38, Brastemp, Manaus, AM, Brazil) for $3 \mathrm{~min}$ at $500 \mathrm{~W}^{17}$. Finally, in group 4, repair materials were chemically polymerized and placed in the flask, under same compression, in water bath $\left(55^{\circ} \mathrm{C} \text { for } 15 \mathrm{~min}\right)^{26}$. This method was conducted in order to improve their physical properties ${ }^{25}$ and standardize the amount of material to be used in the repair. Prior to the flexural strength tests, all specimens were stored again in distilled water at $37^{\circ} \mathrm{C}$ for 1 week.

The three-point bending flexural strength test was conducted in a computerized device for mechanical assays (MTS-810 - MTS Systems Corporation, Eden Praire, MN-USA) with load cell of $100 \mathrm{kgf}$ under constant speed of $5 \mathrm{~mm} / \mathrm{min}^{6}$. Force was applied in the center of the specimens (repair area $)^{4,25}$, in opposition to the supports, with a roundend point. Force was uniformly increased until fracture of the specimens (Figure 2). The maximum load applied was registered and calculated in $\mathrm{N}$.

The maximum load applied was used to calculate the flexural strength by means of the specimens' cross sectional area, according the following equation:

$$
S=\frac{3}{2} \frac{W L}{b d^{2}}
$$

Where: $S=$ transverse strength; $W=$ load at fracture, $L=$ distance between supporting wedges $(50 \mathrm{~mm}) ; b=$ width of the specimen $(10 \mathrm{~mm}) ; d=$ thickness of the specimen $(2.5 \mathrm{~mm})$.

Table 1- Measurements of rupture tension in the MPa, standard deviation (SD), mean and median

\begin{tabular}{lcccc}
\hline & \multicolumn{3}{c}{ Resins } \\
\hline Specimens & Control & Lucitone 550 & Acron MC & Simplex \\
\hline 1 & 158.008 & 37.536 & 41.822 & 7.215 \\
\hline 2 & 153.408 & 35.285 & 46.700 & 7.543 \\
\hline 3 & 153.510 & 38.629 & 44.772 & 6.845 \\
\hline 4 & 157.037 & 34.171 & 44.747 & 8.694 \\
\hline 5 & 157.328 & 36.416 & 42.266 & 6.014 \\
\hline 6 & 158.937 & 35.648 & 45.746 & 7.598 \\
\hline 7 & 155.552 & 36.149 & 42.716 & 5.780 \\
\hline 8 & 154.768 & 34.422 & 40.839 & 6.903 \\
\hline 9 & 156.347 & 35.645 & 39.896 & 5.841 \\
\hline 10 & 154.301 & 36.470 & 41.956 & 5.527 \\
11 & 154.647 & 37.457 & 45.532 & 6.478 \\
\hline 12 & 155.496 & 35.698 & 40.562 & 7.210 \\
\hline 13 & 157.903 & 36.531 & 39.587 & 5.987 \\
\hline 14 & 154.838 & 37.469 & 44.329 & 6.432 \\
\hline 15 & 158.607 & 35.699 & 43.872 & 7.025 \\
\hline SD & 1.832 & 1.205 & 2.257 & 0.856 \\
\hline Mean & 156.046 & 36.215 & 43.023 & 6.742 \\
\hline & 155.552 & 36.149 & 42.716 & 6.845 \\
\hline
\end{tabular}




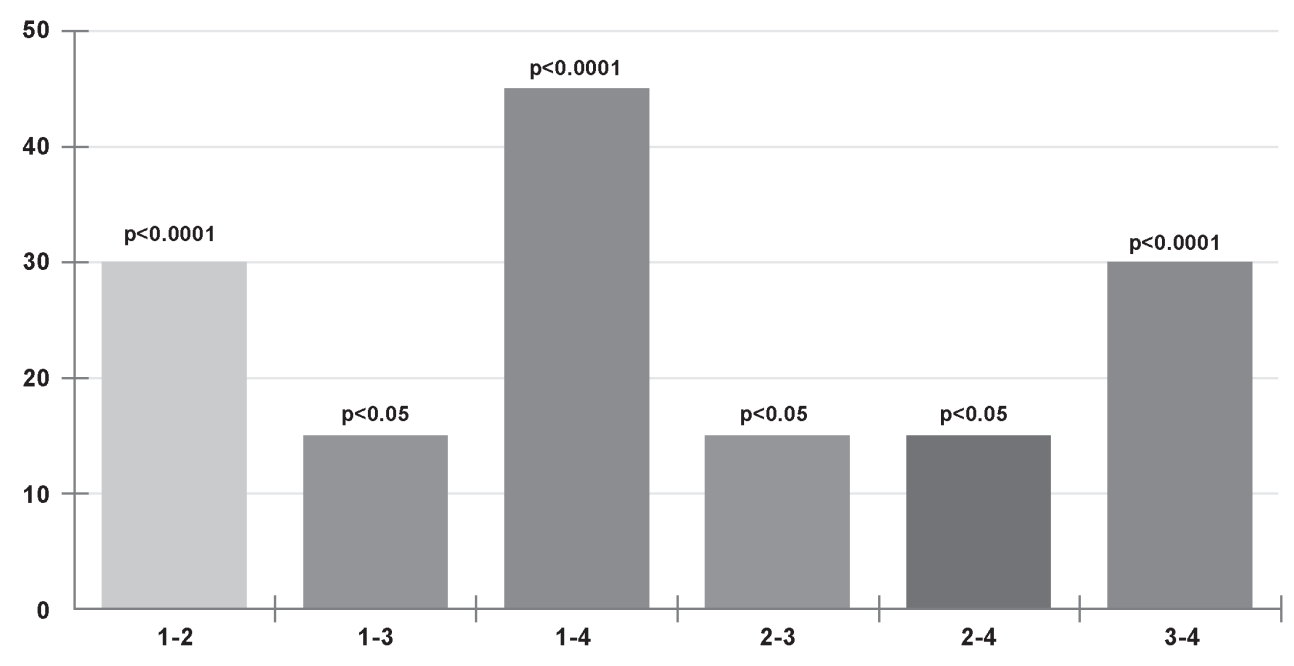

Figure 3- Intergroup comparisons (Kruskal-Wallis; $p<0.05)$

Preliminary analysis of data showed a nonnormal distribution. Thus, the Kruskal-Wallis nonparametric test was adopted to analyze the results $(p<0.05)$ followed by Student-Newman-Keuls test for multiple comparisons. Statistical analysis was done using BioStat 5.0 software (AnalystSoft, Vancouver, BC, Canada).

\section{RESULTS}

Table 1 presents flexural strength values of each group, standard deviation (SD), mean and median for the all groups. There was significant difference among groups $(p<0.05)$, as demonstrated by Kruskal Wallis statistical test and Student-NewmanKeuls for statistical comparison Figure 3.

The best result was demonstrated by group 1 (control) followed by group 3 (microwave), 2 (warm water-bath) and 4 (chemical polymerization), in a decreasing order of strength. The flexural strength of group 3 was up to $27 \%$ of the intact specimens' strength. The types of failures of the specimens were not observed in this study.

\section{DISCUSSION}

This study assessed the flexural strength of 3 different types of acrylic resins, used in the repair of rectangular specimens produced with acrylic resins by different methods of polymerization. The repair material of choice depends on the following factors: length of time required for making the repair, transverse strength obtained with the repair material, and degree to which dimensional accuracy is maintained during the repair. Other important factor is that the increase in the temperature of polymerization improves mechanical and chemical properties of acrylic resins ${ }^{7}$.

All repaired groups demonstrated flexural values lower than that of the intact specimens in this study. The hypothesis tested in this study was thus rejected. It was found in test group that microwave-cured resin had the highest intact transverse strength with a mean value of 43.023 $\mathrm{MPa}$, followed by warm water-bath-cured resin, with a mean value of $36.215 \mathrm{MPa}$ and chemically polymerized resin with a mean value 6.742 $\mathrm{MPa}$.

The increased transverse strength of microwavecured resin (Acron MC) was probably due to the presence of less rubber in its composition as compared to conventional warm water-bathcured resin (Lucitone 550), which makes the last one behave more elastically, demonstrating low final strength values ${ }^{20}$. Moreover, some studies have shown that microwave-cured resins have decreased porosity because the heat necessary to break the benzoyl peroxide molecule into free radicals is created inside the resin once microwave radiations have greater penetrating capability ${ }^{15,20}$. This way, the heat is dispersed more efficiently and polymerization is rapid and decreases residual monomer content as compared to warm waterbath-cured resin.

On the other hand, in this study, chemical polymerizing showed the worst flexural strength values mean, when compared to the others groups, in agreement with other study ${ }^{25}$. This method is the most commonly used for denture repairs in daily practical. However, it has been shown that, not all the monomer is converted to polymer in denture repair, and the level of residual monomer has been demonstrated to affect other properties. It is possible that the repair strength could be improved by effecting further polymerization like microwave energy or warm water-bath ${ }^{28}$. A way to improve the performance of this type of polymerization is that dentures repaired with auto-polymerized acrylic resin should be stored in water for a time between 
$24 \mathrm{~h}$ and 1 week before being installed, allowing to the complete polymerization of the material ${ }^{9}$. However, it is important to consider that in clinical practice there is often urgency in repairing dentures, which make the time recommended by the authors unfeasible, in order to avoid embarrassing situations for the patients.

As all in vitro studies, the present research has limitations. Although this work compared different methods of polymerization, one of the limitations of this study is the use of resins of different commercial brands and compositions. However, the methods can be used safely for comparisons, once it agrees with the studies cited previously $20,25,28$. Further research is needed to evaluate these results under conditions that simulate a clinical situation like thermal cycling and/or cyclic loading.

\section{CONCLUSIONS}

Within the limitations of this in vitro study, the following conclusions were found:

1- The repaired specimens showed lower flexural strength, as compared to the intact specimens (control group);

2- Repairs with autopolymerized acrylic resins showed the lowest flexural strength;

3- Final results are influenced by the repair material.

\section{REFERENCES}

1- Agarwal M, Nayak A, Hallikerimath R. A study to evaluate the transverse strength of repaired acrylic denture resins with conventional heat-cured, autopolymerizing and microwave-cured resins: an in vitro study. The Journal of Indian Prosthodontic Society. 2008;8:36-41.

2- Andreopoulos AG, Polyzois GL, Demetriou PP. Repairs with visible light-curing denture base materials. Quintessence Int. $1991 ; 22: 703-6$.

3- Beyli MS, Von Fraunhofer JA. An analysis of causes of fracture of acrylic resin dentures. J Prosthet Dent. 1981;46:238-41.

4- Beyli MS, Von Fraunhofer JA. Repair of fractured acrylic resin. J Prosthet Dent. 1980;44:497-503.

5- Darbar UR, Huggett R, Harrison A. Denture fracture - a survey. Br Dent J. 1994;176:342-5.

6- Dar-Odeh NS, Harrison A, Abu-Hammad O. An evaluation of selfcured and visible light-cured denture base materials when used as a denture base repair material. J Oral Rehabil. 1997;24:755-60. 7- Doğan A, Bek B, Cevik NN, Usanmaz A. The effect of preparation conditions of acrylic denture base materials on the level of residual monomer, mechanical properties and water absorption. J Dent. 1995;23:313-8.

8- Dyer RA, Howlett JA. Dimensional stability of denture bases following repair with microwave resin. J Dent. 1994;22:236-41. 9- Harrison WM, Stansbury BE. The effect of joint surface contours on the transverse strength of repaired acrylic resin. J Prosthet Dent. 1970;23:464-72.
10- John J, Gangadhar SA, Shah I. Flexural strength of heatpolymerized polymethyl methacrylate denture resin reinforced with glass, aramid, or nylon fibers. J Prosthet Dent. 2001;86:424-7. 11- Karacaer O, Dogan OM, Tinçer T, Dogan A. Reinforcement of maxillary dentures with silane-treated ultra high modulus polyethylene fibers. J Oral Sci. 2001;43:103-7.

12- Keyf F, Uzun G. The effect of glass fibre-reinforcement on the transverse strength, deflection and modulus of elasticity of repaired acrylic resins. Int Dent J. 2000;50:93-7.

13- Leong A, Grant AA. The transverse strength of repairs in polymethyl methacrylate. Aust Dent J. 1971;16: 232-4.

14- Nagai E, Otani K, Satoh Y, Suzuki S. Repair of denture base resin using woven metal and glass fiber: effect of methylene chloride pretreatment. J Prosthet Dent. 2001;85:496-500.

15- Ng ET, Tan LH, Chew BS, Thean HP. Shear bond strength of microwaveable acrylic resin for denture repair. J Oral Rehabil. 2004;31:798-802

16- Polyzois GL, Andreopoulos AG, Lagouvardos PE. Acrylic resin denture repair with adhesive resin and metal wires: effects on strength parameters. J Prosthet Dent. 1996;75:381-7.

17- Polyzois GL, Handley RW, Stafford GD. Repair strength of denture base resins using various methods. Eur J Prosthodont Restor Dent. 1995;3:183-6.

18- Polyzois GL, Tarantili PA, Frangou MJ, Andreopoulos AG. Fracture force, deflection at fracture, and toughness of repaired denture resin subjected to microwave polymerization or reinforced with wire or glass fiber. J Prosthet Dent. 2001;86:613-9.

19- Rached RN, Del-Bel Cury AA. Heat-cured acrylic resin repaired with microwave-cured one: bond strength and surface texture. J Oral Rehabil. 2001;28:370-5.

20- Rached RN, Powers JM, Del Bel Cury AA. Repair strength of autopolymerizing, microwave, and conventional heat-polymerized acrylic resins. J Prosthet Dent. 2004;92:79-82.

21- Shen C, Colaizzi FA, Birns B. Strength of denture repairs as influenced by surface treatment. J Prosthet Dent. 1984;52:844-8. 22- Stipho HD, Stipho AS. Effectiveness and durability of repaired acrylic resin joints. J Prosthet Dent. 1987;58:249-53.

23- Stipho HD, Talic YF. Repair of denture base resins with visible light-polymerized reline material: effect on tensile and shear bond strengths. J Prosthet Dent. 2001;86:143-8.

24- Thean HP, Chew CL, Goh KI, Norman RD. An evaluation of bond strengths of denture repair resins by a torsional method. Aust Dent J. 1998;43:5-8.

25- Vallittu PK, Lassila VP, Lappalainen R. Wetting the repair surface with methyl methacrylate affects the transverse strength of repaired heat-polymerized resin. J Prosthet Dent. 1994;72:63943.

26- Vallittu PK, Ruyter IE. Swelling of poly (methyl methacrylate) resin at the repair joint. Int J Prosthodont. 1997;10:254-8.

27- Ward JE, Moon PC, Levine RA, Behrendt CL. Effect of repair surface design, repair material, and processing method on the transverse strength of repaired acrylic denture resin. J Prosthet Dent. 1992;67:815-20.

28- Yunus N, Harrison A, Huggett R. Effect of microwave irradiation on the flexural strength and residual monomer levels of an acrylic resin repair material. J Oral Rehabil. 1994;21:641-8.

29- Zappini G, Kammann A, Wachter W. Comparison of fracture tests of denture base materials. J Prosthet Dent. 2003;90:578-85. 